\title{
Invitro Evaluation of Fungicides, Botanicals and Bioagents against Colletotrichum truncatum
}

\author{
B. Shashikumara*, B. Rajeswari, G. Uma Devi, G. Sridevi and Somashekhar Konda \\ Department of Plant Pathology, College of Agriculture, \\ Rajendra nagar, PJTSAU Hyderabad-500030, India \\ *Corresponding author
}

\begin{abstract}
A B S T R A C T
Soybean [Glycine max (L.) Merrill.] is an important oilseed crop. Colletotrichum truncatum, the incitant of anthracnose/ pod blight in soybean is one of the most destructive pathogens. Eight fungicides (@ 500, 1000, 1500, 2000 and 2500ppm each), 10 botanicals@ $10 \%$ and four bioagents were evaluated in vitro against $C$. truncatum, using PDA as basal medium. The results revealed that all the fungicides, botanicals and bioagents tested were found fungistatic and significantly inhibited the mycelial growth of the test pathogen over untreated control. Among the fungicides, Carbendazim + Mancozeb and Propiconazole recorded the highest mean inhibition $(100 \%)$ of mycelial growth of the test pathogen, followed by the fungicide, tebunconazole inhibited 100 per cent inhibition at concentration of $1500 \mathrm{ppm}$. Least inhibition was observed in hexaconazole at $500 \mathrm{ppm}$ concentration. Among ten botanicals tested, Garlic extract recorded highest mean mycelial growth inhibition $(53.22 \%)$ of the test pathogen followed by the onion extract (47.11\%), neem (46.44\%).Vavilaku extract $(9.7 \%)$ was found to be the least effective in inhibition of mycelial growth of pathogen. Among the bioagents, T. harzianum recorded highest mean mycelial growth inhibition of 80.22 followed by $T$.viride $(72.55 \%)$.
\end{abstract}

\section{Keywords}

Oilseed crop, soybean, bioagents, test pathogen

Article Info

Accepted:

05 June 2020

Available Online:

10 July 2020

\section{Introduction}

Soybean [Glycine max (L.) Merrill.] has gained importance in India being rich in oil $(20 \%)$ and protein $(40 \%)$. In India, it is grown in an area of 10.96 million hectares with a production of 13.45 million tonnes and productivity of $1228 \mathrm{~kg} / \mathrm{ha}$ (Anonymous, 2018-19). It is cultivated mainly as a kharif crop in the soybean growing states such as Madya pradesh, Maharashtra, Rajasthan, Andhra Pradesh, Karnataka, Chhattisgarh and Telangana state.

However the soybean yields are remarkably low due to various factors of biotic and abiotic nature which take a heavy toll on the crop, of which diseases account for estimated 
yield loss of 12 per cent. Among various diseases on soybean anthracnose causes estimated yield losses of 26 per cent (Backman et al., 1982).

In view of this, in vitro studies were undertaken to evaluate the efficacy of fungicides, botanicals and bioagents in inhibiting mycelial growth of $C$. truncatum.

\section{Materials and Methods}

The experiment was conducted during 2018 at Department of Plant Pathology, College of Agriculture, Rajendranagar.

\section{In vitro evaluation of fungicides against test pathogen}

Eight fungicides viz., mancozeb, carbendazim, tebunconazole, hexaconazole, propiconazole, corboxin + thiram, carbendazim + mancozeb and tebuconazole + triflaxystrobin were tested against C.truncatum at concentrations of $500 \mathrm{ppm}$, 1000 ppm, 1500 ppm, 2000 ppm, 2500 ppm, on potato dextrose agar media using poison food technique(Nene and Thapliyal, 1993). under in vitro conditions.

The PDA medium was prepared and melted. The fungicidal suspension was added to the melted media to obtain the required concentrations. About $20 \mathrm{ml}$ of poisoned medium was poured in each sterilized petriplates. Suitable check was maintained without addition of fungicides.

Five mm mycelial disc was taken from the periphery of eight days old colony was placed in the centre of petriplates and incubated at 28 $\pm 2^{0} \mathrm{C}$ for 15 days. Three replications were maintained for each treatment. The diameter of the colony was measured when maximum growth of the pathogen was observed in control plates.
In vitro evaluation of botanicals against test pathogen

Aqueous extracts of different plant species were used to determine the toxicant properties against $C$. truncatum. Fifty grams of fresh healthy plant parts (leaves/rhizome/bulbs) collected from field were washed with distilled water, air-dried and crushed in $50 \mathrm{ml}$ of sterile water. The crushed product was filtered through muslin cloth and collected the filtrate. The prepared solution gave 100 per cent which was further diluted to required concentrations of 10.0 per cent. The extracts were tested using poisoned food technique (Nene and Thapliyal, 1993) against $C$. truncatum on the potato dextrose agar under in vitro conditions.

In vitro evaluation of biogents against test pathogen

Bioagents viz., Trichoderma harzianum, Trichoderma virens, Pseudomonas fluorescens and Bacillus subtilis were evaluated for their effectiveness against $C$. truncatum under laboratory conditions. Dual culture technique (Dennis and Webster, 1971) was adopted to evaluate the biocontrol agents under laboratory conditions. The fungal bioagents and the test fungus were inoculated side by side on a single Petridish containing solidified PDA medium. To test the efficacy of bacterium, a $4 \mathrm{~cm}$ line was streaked at four corners of the plate. At the centre of the antagonist, a $6 \mathrm{~mm}$ diameter mycelial disc of test the fungus was placed. The Petri plates with pathogen inoculated at one end alone served as control. Three replications were maintained for each treatment with one control by maintaining only pathogen and bioagents separately. The plates were incubated at $27 \pm 2^{\circ} \mathrm{C}$ and the diameter of the colony of both bioagents and the pathogen was measured when maximum growth of the pathogen was observed in control plates. 
Observations on radial mycelial growth of $C$. truncatum were recorded in each treatment and per cent growth inhibition of the test pathogen over control was worked out (Vincent, 1927) as follows.

$I=\frac{C-T}{C} \times 100$

Where,

I : Per cent reduction in growth of the antagonistic fungus

$\mathrm{C}$ : Radial growth of antagonistic fungus in control (mm)

$\mathrm{T}$ : Radial growth of antagonistic fungus in treatment $(\mathrm{mm})$

\section{Results and Discussion}

\section{Effect of fungicides}

The results (Table 1, Plate. 1 and Fig. 1) revealed that mancozeb inhibited the mycelial growth of the test pathogen to an extent of 76.44 per cent at $2500 \mathrm{ppm}$ concentration. Significant differences were observed among the systemic fungicides concentrations and interactions. Propiconazole inhibited 100 per cent mycelial growth of $C$. truncatum at all the five concentrations tested (500, 1000, 1500, 2000, 2500 ppm). Carbendazim inhibited 84.11 per cent of mycelial growth of C. truncatum at concentration of $2500 \mathrm{ppm}$ whereas tebunconazole inhibited 100 per cent inhibition in mycelial growth of $C$. truncatum at concentration of $1500 \mathrm{ppm}$. Least inhibition in mycelial growth of $C$. truncatum was observed in hexaconazole at 500 ppm concentration.

Among the combi products, carbendazim + mancozeb was the best in inhibiting 100 per cent mycelial growth of $C$. truncatum at all the five concentrations of $(500,1000,1500$, 2000, $2500 \mathrm{ppm}$ ) followed by tebuconazole + trifloxystrobin 88.9 per cent at 500 ppm concentration. Among the combi products tested, the least mycelial growth inhibition was observed in carboxin +thiram with inhibition in mycelial growth of 84.04 per cent.

The present results were in accordance with the studies conducted by Nagaraj (2013) who reported that propiconazole and trifloxystrobin +tebuconazole were effective against $C$. truncatum inciting anthracnose of soybean at $500 \mathrm{ppm}, 1000 \mathrm{ppm}$ and $1500 \mathrm{ppm}$ concentration. Similarly Kale and Barhate (2016) also reported that propiconazole and hexoconazole at 0.1 per cent concentration inhibited the mycelial growth of the pathogen to an extent of 78.15 per cent and 84.44 per cent respectively. Shovan et al., (2008) also reported that propiconazole completely inhibited the mycelial growth of $C$. truncatum. Gawade et al., (2009) reported that carbendazim recorded the highest mean inhibition in mycelial growth of the test pathogen followed propiconazole, hexaconazole, difenconazole and chlorothalonil at $100 \mathrm{ppm}, 150 \mathrm{ppm}$ and 200 ppm concentrations.

\section{Effect of bioagent}

It was observed $T$. harzianum gave highest mycelial growth inhibition of the pathogen $(80.22 \%)$ which was followed by T.viridae $(72.55 \%)$. The least inhibition of the fungus was observed in $P$. fluorescens $(46.44 \%)$ and Bacillus subtilis $(36.00 \%)$. (Table 2, Fig. 2 and Plate 2).

The present findings are in agreement with the studies conducted by Medereiros and Menezas. 1994, Pathania et al., (2004) and Laxman (2006). Kale and Barhate (2016) reported that $T$. viride was effective against C. truncatum inciting anthracnose of soybean. 
Table.1 Efficacy of different fungicides on radial growth of Colletotrichum truncatum in vitro

\begin{tabular}{|c|c|c|c|c|c|c|c|}
\hline \multirow[t]{3}{*}{ SI.No. } & \multirow[t]{3}{*}{ Fungicides } & \multicolumn{6}{|c|}{ Percent inhibition of the mycelial growth of fungus } \\
\hline & & \multicolumn{5}{|c|}{ Concentrations (ppm) } & \multirow[t]{2}{*}{ Mean } \\
\hline & & 500 ppm & $\begin{array}{l}1000 \\
\text { ppm }\end{array}$ & $\begin{array}{l}1500 \\
\text { ppm }\end{array}$ & $\begin{array}{l}2000 \\
\text { ppm }\end{array}$ & $\begin{array}{l}2500 \\
\text { ppm }\end{array}$ & \\
\hline 1. & Mancozeb & $\begin{array}{c}56.44 \\
(48.70)^{*}\end{array}$ & $\begin{array}{c}59.33 \\
(50.38)\end{array}$ & $\begin{array}{r}67.00 \\
(54.94)\end{array}$ & $\begin{array}{r}70.88 \\
(57.35)\end{array}$ & $\begin{array}{r}76.44 \\
(60.98)\end{array}$ & $\begin{array}{r}66.01 \\
(54.12)\end{array}$ \\
\hline 2. & Carbendazim & $\begin{array}{c}65.33 \\
(53.93)\end{array}$ & $\begin{array}{c}68.00 \\
(55.56)\end{array}$ & $\begin{array}{c}70.77 \\
(57.28)\end{array}$ & $\begin{array}{c}77.44 \\
(61.66)\end{array}$ & $\begin{array}{c}84.11 \\
(66.62)\end{array}$ & $\begin{array}{c}73.13 \\
(62.52)\end{array}$ \\
\hline 3. & Tebuconazole & $\begin{array}{c}72.66 \\
(58.48)\end{array}$ & $\begin{array}{c}78.88 \\
(62.66)\end{array}$ & $\begin{array}{c}100 \\
(85.95)\end{array}$ & $\begin{array}{c}100 \\
(85.95)\end{array}$ & $\begin{array}{c}100 \\
(85.95)\end{array}$ & $\begin{array}{c}90.30 \\
(72.56)\end{array}$ \\
\hline 4. & Hexaconazole & $\begin{array}{c}57.11 \\
(49.09)\end{array}$ & $\begin{array}{c}62.88 \\
(52.47)\end{array}$ & $\begin{array}{c}67.44 \\
(55.21)\end{array}$ & $\begin{array}{l}70.55 \\
(61.76)\end{array}$ & $\begin{array}{c}77.44 \\
(61.66)\end{array}$ & $\begin{array}{c}67.08 \\
(55.02)\end{array}$ \\
\hline 5. & Propiconazole & $\begin{array}{c}100 \\
(85.95)\end{array}$ & $\begin{array}{c}100 \\
(85.95)\end{array}$ & $\begin{array}{c}100 \\
(85.95)\end{array}$ & $\begin{array}{c}100 \\
(85.95)\end{array}$ & $\begin{array}{c}100 \\
(85.95)\end{array}$ & $\begin{array}{c}100 \\
(85.95)\end{array}$ \\
\hline 6. & $\begin{array}{l}\text { Carboxin }+ \\
\text { Thiram }\end{array}$ & $\begin{array}{c}84.04 \\
(66.48)\end{array}$ & $\begin{array}{c}100 \\
(85.95)\end{array}$ & $\begin{array}{c}100 \\
(85.95)\end{array}$ & $\begin{array}{c}100 \\
(85.95)\end{array}$ & $\begin{array}{c}100 \\
(85.95)\end{array}$ & $\begin{array}{c}96.80 \\
(82.36)\end{array}$ \\
\hline 7. & $\begin{array}{l}\text { Carbendazim+ } \\
\text { Mancozeb }\end{array}$ & $\begin{array}{c}100 \\
(85.95)\end{array}$ & $\begin{array}{c}100 \\
(85.95)\end{array}$ & $\begin{array}{c}100 \\
(85.95)\end{array}$ & $\begin{array}{c}100 \\
(85.95)\end{array}$ & $\begin{array}{c}100 \\
(85.95)\end{array}$ & $\begin{array}{c}100 \\
(85.95)\end{array}$ \\
\hline 8. & $\begin{array}{l}\text { Tebuconazole+ } \\
\text { Trifloxystrobin }\end{array}$ & $\begin{array}{c}88.9 \\
(70.59)\end{array}$ & $\begin{array}{c}100 \\
(85.95)\end{array}$ & $\begin{array}{c}100 \\
(85.95)\end{array}$ & $\begin{array}{c}100 \\
(85.95)\end{array}$ & $\begin{array}{c}100 \\
(85.95)\end{array}$ & $\begin{array}{c}97.78 \\
(83.18)\end{array}$ \\
\hline 9. & Control & $\begin{array}{c}0.00 \\
(0.00)\end{array}$ & $\begin{array}{c}0.00 \\
(0.00)\end{array}$ & $\begin{array}{c}0.00 \\
(0.00)\end{array}$ & $\begin{array}{c}0.00 \\
(0.00)\end{array}$ & $\begin{array}{c}0.00 \\
(0.00)\end{array}$ & $\begin{array}{c}0.00 \\
(0.00)\end{array}$ \\
\hline & Mean & $\begin{array}{c}69.38 \\
(58.13)\end{array}$ & $\begin{array}{c}74.34 \\
(63.10)\end{array}$ & $\begin{array}{c}78.35 \\
(66.80)\end{array}$ & $\begin{array}{c}77.36 \\
(65.07)\end{array}$ & $\begin{array}{c}82.01 \\
(69.22)\end{array}$ & \\
\hline & S. Em \pm & 0.65 & 0.48 & 0.41 & 0.50 & 0.46 & \\
\hline & CD@5\% & 1.94 & 1.42 & 1.22 & 1.50 & 1.37 & \\
\hline
\end{tabular}

All the figures are means of three replications

*Figures in parenthesis are angular transformed values 
Table.2 Evaluation of bioagents on radial growth of Colletotrichum truncatum in vitro

\begin{tabular}{|c|c|c|}
\hline Sl.No. & Bio-agents & $\begin{array}{l}\text { Per cent inhibition of the } \\
\text { mycelial growth of fungus }\end{array}$ \\
\hline 1. & Trichoderma harzianum & $\begin{array}{c}80.22 \\
(63.61) *\end{array}$ \\
\hline 2. & Trichoderma viride & $\begin{array}{c}72.55 \\
(58.41)\end{array}$ \\
\hline 3. & Pseudomonas fluorescens & $\begin{array}{c}46.44 \\
(42.96)\end{array}$ \\
\hline 4. & Bacillus subtilis & $\begin{array}{c}36.00 \\
(34.87)\end{array}$ \\
\hline \multirow[t]{4}{*}{5.} & Control & $\begin{array}{c}0.00 \\
(0.00)\end{array}$ \\
\hline & Mean & $\begin{array}{c}47.04 \\
(41.18)\end{array}$ \\
\hline & S.E $\mathrm{m} \pm$ & 0.65 \\
\hline & $\mathrm{CD}$ at $5 \%$ & 2.06 \\
\hline
\end{tabular}

All the figures are means of three replications

*Figures in parenthesis are angular transformed values

Table.3 Evaluation of botanicals on the radial growth of Colletotrichum truncatum in vitro

\begin{tabular}{|c|c|c|c|}
\hline Sl. No. & Botanicals & $\begin{array}{l}\text { Plant parts } \\
\text { used }\end{array}$ & $\begin{array}{l}\text { Per cent inhibition of the mycelial } \\
\text { growth of fungus }\end{array}$ \\
\hline 1. & Mehandi & Leaves & $\begin{array}{c}39.66 \\
(39.03)^{*}\end{array}$ \\
\hline 2. & Onion & Bulb & $\begin{array}{c}47.11 \\
(43.34)\end{array}$ \\
\hline 3. & Garlic & Bulb & $\begin{array}{c}53.22 \\
(46.85)\end{array}$ \\
\hline 4. & Ginger & Rhizome & $\begin{array}{c}37.55 \\
(37.79)\end{array}$ \\
\hline 5. & Neem & Leaves & $\begin{array}{c}46.44 \\
(42.96)\end{array}$ \\
\hline 6. & Prosopis & Leaves & $\begin{array}{c}34.33 \\
(35.86)\end{array}$ \\
\hline 7. & Bougainvillia & Leaves & $\begin{array}{c}39.66 \\
(39.03)\end{array}$ \\
\hline 8. & Vincarosea & Leaves & $\begin{array}{l}44.66 \\
(41.93)\end{array}$ \\
\hline 9. & Pongamia & Leaves & $\begin{array}{c}37.66 \\
(37.85)\end{array}$ \\
\hline \multirow[t]{5}{*}{10.} & Vavilaku & Leaves & $\begin{array}{c}9.70 \\
(18.09)\end{array}$ \\
\hline & Control & & $\begin{array}{c}0.00 \\
(0.00)\end{array}$ \\
\hline & Mean & & $\begin{array}{c}35.45 \\
(35.16)\end{array}$ \\
\hline & S.E m \pm & & 0.69 \\
\hline & $\mathrm{CD}$ at $5 \%$ & & 2.04 \\
\hline
\end{tabular}

All the figures are means of three replications

All botanicals were tested against $C$. truncatum at 10 per cent concentration

*Figures in parenthesis are angular transformed values 


\section{Effect of botanicals}

The results (Table 3, Fig. 3 and Plate 3) revealed that, among the ten botanicals evaluated in vitro against $C$. truncatum, significantly the highest inhibition was obtained by garlic extract $(53.22 \%)$ and it was followed by onion extract $(47.11 \%)$, Neem extract $(46.44 \%)$ and Vincarosea extract $(44.66 \%)$ and were significantly superior over Mehindi extact (39.66\%), Bougainvillia extract (39.66\%), Pongamia extract (37.66\%), ginger extract $(37.55 \%)$ and prosopis $(34.33 \%)$. Vavilaku extract $(9.7 \%)$ was found to be the least effective in inhibition of mycelial growth of pathogen. The present findings are in agreement with the studies conducted by earlier workers Kulkarni (2009), Gawade et al., (2009).

\section{References}

Annonymous, Directorate of Economics and Statistics, Ministry of Agriculture and Farmer Welfare. 2019.

Backman, P. A., Williams, J. C and Crawford, M. A. 1982). Plant Disease. 66(11): 1032- 1034.

Dennis, C and Webster, J. 1971.Antagonistic properties of species-groups of Trichoderma. I. Production of nonvolatile antibiotics. Transaction of British Mycological Society.57: 25-39.

Gawade, D.B., Suryawansh, A.P., Zape, A.S., Zagade, S.N and Wadje, A.G. 2009. In vitro Evaluation of Fungicides, Botanicals and Bioagents Against Soybean Anthracnose Incited by Colletotrichum truncatum.International Journal of Plant Protection. 2 (1): 103-
107.

Kale, S.L and Barhate, B.G. 2016. Management of anthracnose in soybean caused by Colletotrichum truncatum. International Journal of Plant Protection. 9(2): 583-588.

Laxman, R. 2006, Studies on leaf spot of greengram caused by Colletotrichum truncatum (Schw.) Andrus and Moore. M. Sc. (Agri.) Thesis, University of Agricultural Science, Dharwad. 62-64.

Medereiros, S. A. F and Menezas, M. 1994. Antagonistic potentials of some fungi to Colletotrichum gloeosporioides causal agent of cashew tree (Anacardium occidentalis) anthracnose. Fitopathologia Brasileria. 19 (1): 8491.

Nagaraj, B. T. 2013. Studies on soybean anthracnose caused by Colletotrichum truncatum (Schw.) Andrus and Moore. M.Sc. (Agri) Thesis, Univ. Agril. Sci., Dharwad. pp 78-82.

Nene, Y.L and Thaplyal, P.N. 1993. Evaluation of fungicides. In : Fungicides in plant disease control (3rd ed.) Oxford, IBH Publishing Co., New Delhi. 331pp.

Shovan, L.R., Bhuiyan, M.K.A., Begum J.A and Pervez, Z. 2008. In vitro Control of Colletotrichum truncatum causing anthracnose of soybean by fungicides, plant extracts and Trichoderma harzianum. International Journal of Sustainable Crop Production. 3 (3):1017.

Vincent, J. M. 1947. Distortion of fungal hyphae in presence of certain inhibitors. Nature. 159: 239-241.

\section{How to cite this article:}

Shashikumara. B., B. Rajeswari, G. Uma Devi, G. Sridevi and Somashekhar Konda. 2020. Invitro Evaluation of Fungicides, Botanicals and Bioagents Against Colletotrichum truncatum. Int.J.Curr.Microbiol.App.Sci. 9(07): 551-556. doi: https://doi.org/10.20546/ijcmas.2020.907.061 